\title{
REVIEW
}

\author{
LISANNE WILKEN
}

\section{ANTROPOLOGIEN OG DEN EUROPÆISKE UNION}

I det seneste tiår er der sket store forandringer i Europa. Den Kolde Krig er slut, Berlinmuren revet ned, Sovjetunionen opløst, Tyskland genforenet, Tjekkoslovakiet delt, Jugoslavien splittet, og store dele af Vesteuropa er forenet i en politisk union. Også i antropologien er der sket forandringer. Der har været en mærkbar vækst i interessen for Europa, og navnlig Østeuropa har tiltrukket sig antropologisk opmærksomhed. Men der er også sket noget i forhold til Vesteuropa. Den Europæiske Union, der ellers i påfaldende grad har glimret ved sit fravær i Europa-antropologien, optræder i stadig flere antropologiske analyser. Enten som betydningsskabende ramme for og direkte medspiller i samfundsog kulturproduktionen i Europa eller som analyseobjekt i sig selv. Og selv om der endnu ikke er tale om masseproduktion, tegner der sig så småt konturerne af noget, man kunne kalde ,en antropologi om Den Europæiske Union“.

\section{En overset forening}

Den Europæiske Union er et af de største og mest befolkede sociale systemer, der er konstrueret i nyere tid. Det er også et af de mest oversete - $\mathrm{i}$ hvert fald i antropologien. Faktisk skulle der gå 30 år fra Romtraktaten trådte i kraft, før den første antropologiske analyse af en EF-relateret problemstilling blev publiceret (Giordano 1987). Og der skulle gå endnu nogle år, før de første antologier udkom (Wilson \& Smith 1993; Goddard, Llobera \& Shore 1994), og med dem de første mere overordnede bud på en antropologi om Fællesskabet. Den hidtidige mangel på antropologisk interesse for Det Europæiske Fællesskab er i virkeligheden besynderlig. Både fordi der er en lang og omfattende antropologisk tradition for at beskæftige sig med Europa (opsummeret hos Cole 1977; MacDonald 1993), og fordi Europa-antropologien siden midten af 1970'erne har søgt at kombinere etnografiske mikrostudier med studiet af makrosociologiske processer (se f.eks. Boissevain 1975; Grillo 1980). Men også fordi virkningerne af fællesskabskonstruktionen ret hurtigt blev synlige - ikke mindst i de bonde- og minoritetssamfund, som antropologer i høj grad har gjort feltarbejde i. Store dele af det vesteuropæiske landbrug - og med det levevilkårene i landområderne - blev omlagt i 1960'erne og i 1970'erne som en direkte virkning af EF-konstruktionen og på måder, som ingen enkelt nationalstat kunne have 
forestået (Shutes 1993). Og vesteuropæiske minoriteter begyndte allerede i starten af 1980 'erne at orientere sig mod Det Europæiske Fællesskab og at betragte de europæiske institutioner som samarbejdspartnere og allierede (Wilken n.d.).

Men kan det være vanskeligt at forstå, hvorfor antropologer konsekvent overså EF i de første 30 år, er det lettere at forklare, hvorfor interessen for Fællesskabet opstod i slutningen af 1980'erne. Der er nemlig ingen tvivl om, at omvæltningerne i Østeuropa og i det tidligere Sovjet var med til at gøre Fællesskabet relevant. Både fordi det var dén forenende politiske og $\emptyset$ konomiske struktur, der fandtes i Europa, og fordi de østeuropæiske samfund meget hurtigt begyndte at orientere sig mod Fællesskabet. EF kom med andre ord til at fremstå som et konkret bud på „Europa“, som det nok var værd at se nærmere på.

Der er heller ingen tvivl om, at de store omlægninger af samarbejdet, som fandt sted i anden halvdel af 1980'erne, gjorde fællesskabskonstruktionen meget mere synlig og meget mere uomgængelig, end den hidtil havde været - ikke bare i minoritetsområder og i landbrugssamfund, men i næsten alle aspekter af samfundslivet i Vesteuropa. Vedtagelsen af Fællesakten i 1986 satte kursen mod et indre marked i et Europa uden grænser. Ændringer i den fælles landbrugspolitik førte igen til flere omlægninger - og store problemer - i landbrugsområderne. Overflyttelsen af konkret politisk og økonomisk magt fra medlemstaterne til fællesskabsinstitutionerne gav Fællesskabet indflydelse på nationalpolitiske forhold, og skabte grobund for en direkte dialog mellem befolkningsgrupper i medlemsstaterne og Fællesskabets institutioner. Og de 282 harmoniseringsdirektiver, som skulle bane vejen for Det Indre Marked, og som berører alt fra måleenheder og osteproduktion til miljøregler og uddannelsesforhold, greb direkte ind i dagliglivet i de europæiske samfund. Hertil kommer, at Det Europæiske Fællesskab i 1993 blev omdannet til en politisk Union. Den ændrede kontekst for det europæiske samarbejde og ændringerne i samarbejdets karakter har sat Den Europæiske Union på den antropologiske dagsorden. Men den manglende interesse for fællesskabskonstruktionen i de første 30 år sætter i øjeblikket rammerne for den forskning, der frembringes.

\section{Nye læsere kan begynde her}

Antropologien om Den Europæiske Union er et forskningsfelt under opbygning. Der findes endnu ikke et fælles fagligt fundament for forståelsen af det komplicerede unionsforetagende, og der findes ikke en fælles antropologisk basisviden, som man kan referere til. De hidtidige antropologiske bidrag bærer da også præg af, at både ,tekst“ og ,kontekst" skal forklares indgående. Man kan for eksempel ikke forudsætte, at læsere på forhånd er bekendt med, at Gatt-forhandlingerne har betydning for konstruktionen af Det Indre Marked - eller at de ved, hvad Gatt-forhandlinger eller Det Indre Marked går ud på. Man kan heller ikke forudsætte, at de kender detaljerne i Den Fælles Landbrugspolitik (CAP), eller i Fællesakten (SEA), eller ved, hvem der har den konkrete beslutningsmyndighed over hvilke EU-fonde, og hvad det betyder for relationer mellem lokalområder, medlemstater, lobbyorganisationer og samarbejdsinstitutioner. Man er nødt til at introducere en ny og omfangsrig viden, og det betyder ganske vist, at de fleste antropologiske artikler om Unionen og dens betydning er vældig informative. Men det betyder også, at det kan være vanskeligt at skabe sig et generelt overblik. 
Der er dog hjælp at hente i enkelte af de bidrag, der indtil videre er udkommet (se også Knudsen \& Wilken 1996). Et godt sted at starte er Martin J. Bulls artikel „Widening versus Deepening The European Community: The Political Dynamics of 1992 in Historical Perspective“ (1993). Den giver en glimrende introduktion til unionens historiske udvikling fra de tidlige fors $\emptyset \mathrm{g}$ på at grundlægge et europæisk samarbejde i årene efter 2 . Verdenskrig og frem til vedtagelsen af Maastrichttraktaten om Den Politiske Union. Bull lægger - til forskel fra andre antropologer, der har beskæftiget sig med grundlaget for det europæiske samarbejde (f.eks. Llobera 1994, Varenne 1994) - vægt på, at samarbejdet har udviklet sig i et delt Europa, hvor Wien og Berlin ikke længere var så betydningsfulde som Paris og London, og hvor Europas største problem ikke længere var at rumme Tyskland, men at forholde sig til Sovjetunionen og satellitstaterne i Østeuropa (Bull 1993:26-9) - en vinkel, der måske kan få betydning for analyser af forsøgene på at integrere Østeuropa i EU, fordi den sætter fokus på det vesteuropæiske snarere end på det europæiske fundament for samarbejdet.

Bulls artikel rummer også en informativ analyse af Fællesskabets institutionelle opbygning. Her viser han, at den modsætning mellem et overnationalt og et mellemstatsligt samarbejde, der præger både diskussionerne om det europæiske samarbejde i medlemstaterne, og forskellige staters visioner om samarbejdets udvikling, er indbygget i konstruktionen af EU. EU har nemlig af forskellige årsager, som analyseres i artiklen (op.cit.:29-33), udviklet både overnationale (Parlamentet, Kommissionen) og mellemstatslige (Ministerrådet) institutioner. Og det giver ikke bare meget vide rammer for fortolkninger af, hvad samarbejdet i grunden går ud på. Det skaber også et glimrende grundlag for konfliktuelle visioner om Europas politiske udvikling.

\section{Staternes eller Regionernes Europa}

To af de mest betydningsfulde visioner for Europas udvikling er formuleret som henholdsvis staternes og regionernes Europa. Staternes Europa står for et omfattende mellemstatsligt samarbejde, hvor nationalstaterne, som vi kender dem, bevarer størst mulig suverænitet, hvor de fleste politiske samarbejdsaftaler er mellemstatslige, og hvor kun få og udvalgte politiske beslutninger træffes i overnationalt regi. Regionernes Europa står derimod for en nedlæggelse af de europæiske nationalstater og for en omfordeling af den politiske magt. De politiske beslutninger, der vedrører Fællesskabet, skal træffes i overnationale institutioner, mens alle andre politiske beslutninger skal træffes regionalt. Begge visioner findes $i$ et utal af udgaver.

Diskussionen om staternes og regionernes Europa er udgangspunkt for Alexandra Jaffes analyse af Korsika i EU-ropa (Jaffe 1993). Jaffes artikel er både en introduktion til den overordnede EU-diskussion, og til den EU-diskurs som findes på Korsika. Den er et fornemt eksempel på, hvordan en etnografisk analyse af et lokalområde både kan belyse overordnede EU-problemstillinger, og kan vise, hvordan forståelsen af sådanne problemstillinger nødvendigvis må være både socialt, kulturelt, politisk og økonomisk kontekstualiserede.

På Korsika er man, som i så mange andre - men ikke i alle - perifere minoritetsområder generelt positive over for ideen om regionernes Europa. Det er ikke umiddelbart over- 
raskende. En regional europæisk konstruktion ville betyde, at en væsentlig del af den magt, som den franske stat i dag har over Korsika, ville blive flyttet til øen (op.cit.: 63-4). Det er heller ikke overraskende, fordi Korsika i lighed med andre periferier og minoritetsområder har oplevet, at det er lettere at forhandle direkte med Bruxelles, end med den nationale regering. Betydningsfuldt er det sikkert også, at mens Korsika i fransk sammenhæng er en periferi, kan øen sandsynligvis opnå en vis politisk og $\varnothing$ konomisk centralitet mellem det kontinentale Europa og Nordafrika, hvis den får større politisk og økonomisk råderum (ibid.). Men selv om visionen om regionernes Europa har sine begejstrede fortalere på Korsika, har den også sine skeptikere. Det europæiske samarbejde har i de senere år fremvirket en massiv korsikansk tilnærmelse til Italien, og navnlig mellem Korsika og Midtitalien er der blevet etableret en række samarbejdsprojekter (op.cit.:66-8). Tilnærmelsen til Italien repræsenterer i sig selv en rekontekstualisering af kultur- og identitetsdiskussioner på Korsika, men den har også placeret Korsika i første parket, når det gælder iagttagelsen af den særlige variation af „Regionernes Europa“, der i øjeblikket praktiseres i Italien. Og både den voksende nord- og midtitalienske utålmodighed med Syditalien, og Lombardiets engagement i ,de fire motorregioners “1 samarbejde, giver et fingerpeg om, hvad det er for en type solidaritet, fattige og perifere regioner kan forvente sig af rige og centrale regioner. Og det antyder, at regionernes Europa ikke nødvendigvis vil stille de fattigere områder bedre, end staternes Europa allerede gør (op.cit.:71).

En anden kontekst for korsikanernes diskussion af regionernes Europa udgøres af de samarbejder mellem minoritetsområder, som er blevet etableret inden for Den Europæiske Union. Korsika har ganske vist ikke været meget aktiv i disse minoritetssamarbejder - måske fordi korsikanere i højere grad betragter sig som en ønation end som en europæisk minoritet i lighed med f.eks. waliserne, skotterne eller bretonerne. Men noget samarbejde indgår de $\mathrm{i}$, navnlig med sydeuropæiske (mediterrane) minoriteter. $\mathrm{Og}$ en af de konklusioner, de har draget af dette samarbejde, er, at de minoriteter, der har de bedste vilkår i Vesteuropa i dag, har opnået dem gennem samarbejde med regeringen i den stat, de er placeret i. Dette har interessant nok fået korsikanske nationalister til at genoverveje deres relationer til Frankrig. For det er, i hvert fald i den nære fremtid, gennem relationerne til Frankrig, at regionernes Europa skal skabes (op.cit.:70).

\section{Europa med og uden grænser}

En af de politiske og $\emptyset$ konomiske visioner med det europæiske samarbejde er at skabe et Europa uden grænser. Det er en vision, der binder an til det idealistiske grundlag for Fællesskabet, nemlig forsøget på at knytte de europæiske folk tættere sammen. I sin praktiske politiske udformning hænger den dog mere sammen med konstruktionen af Det Indre Marked, som skal sikre fri bevægelighed af varer, kapital og folk i Unionen. Forsøget på at nedlægge, eller i hvert fald nedtone, de europæiske grænser blev et konkret politisk mål med vedtagelsen af Fællesakten i 1986. Og det har vidtrækkende konsekvenser både for indretningen af de europæiske samfund og for måderne, de tænkes på. For antropologer, der har en lang tradition for at beskæftige sig med grænser såvel teoretisk som empirisk, er det oplagt at se på det EU-ropæiske grænseprojekt i relation til konkrete samfund.

En af de antropologer, der har gjort det, er Thomas Wilson. I artiklen ,Frontiers Go But Boundaries Remain: The Irish Border as a Cultural Divide“ (1993), ser han nærmere 
på EU's grænseprojekt i relation til den internationale grænse mellem Nordirland og Den Irske Republik. Artiklen har to formål. Det ene er at forholde sig kritisk til den EU-ropæiske brug af grænsebegrebet, som relativt snævert definerer grænser som politiske og økonomiske skillelinier, og i høj grad overser, at grænser også har symbolske og sociokulturelle betydninger (Wilson 1993:170). Det andet er at vise, at forsøget på at nedlægge de internationale grænser i EU vil få - og allerede har haft - stor betydning både for de involverede stater og for livet i de europæiske grænseregioner (op.cit.:168).

Forsøget på at skabe et Europa uden grænser påvirker de europæiske samfund på mindst to måder. På den ene side sker der en økonomisk og handelspolitisk harmonisering mellem samfund på begge sider af en grænse, som har helt konkrete og synlige effekter. I det irske tilfælde har navnlig EU's subsidiepolitik (som faktisk har virket i en sådan grad, at Republikken meget længe hørte til blandt de få lande, som opfyldte kravet til ØMU'en), sammen med den britiske inflation og den EU-ropæiske tarifharmonisering udvirket en $\emptyset$ konomisk nivellering mellem Nord og Syd. Denne nivellering påvirker f.eks. handlen i grænseområdet, og det påvirker igen den sociale organisering af det økonomiske liv. Hvor navnlig sydirere tidligere valfartede til Nordirland for at købe ind, bliver de i dag hjemme, hvilket sjovt nok betyder, at forsøget på at nedtone grænsen har medført, at der er færre incitamenter til at krydse den (op.cit.:177-8). Det er i øvrigt ikke kun den legale handel, der påvirkes. Også smugleriet, som spiller en betydningsfuld, om end sparsomt dokumenteret rolle i det socioøkonomiske liv omkring grænsen, er i disse år under omlægning - men ikke under afvikling (ibid.).

På den anden side har forsøgene på at nedlægge grænser også placeret spørgsmålet om deres betydning centralt i de kulturelle og politiske debatter. I Irland, hvor de fleste mennesker hidtil har anset grænsen for både at være en skillelinie mellem stater og mellem kulturer (op.cit.:168-70, 172), kompliceres dette spørgsmål voldsomt af, at grænsens eksistens også er det symbolske omdrejningspunkt for en krig, og at begge Irlande har deres tilhængere af regionernes Europa, som af andre grunde end IRA's og Sinn Feins går ind for nedlæggelse af statsgrænser (Ruane \& Todd 1991).

Diskussionerne om grænsens betydning foregår på baggrund af en enorm usikkerhed om, hvad „Europa uden Grænser“ egentlig indebærer. Vil en nedlæggelse af grænsen f.eks. betyde, at Republikken får politisk indflydelse i Nordirland? Eller at Irland bliver én europæisk region? Vil EU i virkeligheden medføre en samling af Irland, som gør den protestantiske majoritet i Nordirland til en minoritet i et overvejende katolsk Irland, eller vil man f.eks. i et regionernes Europa kunne få skilt kulturelle, religiøse og politiske spørgsmål så tilpas meget ad, at de negative konsekvenser af en statsgrænse forsvinder, samtidig med at de positive effekter af irske forskelligheder styrkes? (se også Ruane 1994). Usikkerheden forstærkes af Storbritanniens dobbelttydige politik i forhold til Irland og i forhold til grænser mod Europa. På den ene side har Storbritannien i længere tid søgt at finde en politik, der kunne føre de to Irlande tættere sammen. På den anden side har de også helt konkret investeret 10 mio. pund i en udbyggelse af grænsekontrollen mellem Nordirland og Republikken (Wilson 1993:183). ${ }^{2}$

Internationale grænser bliver ofte betragtet som yderpunkter. De befinder sig derude, hvor et land slutter, og et andet begynder. En af Wilsons (og antropologiens) pointer er, at sådan forholder det sig ikke bare. Beboerne i en grænseregion anskuer ofte grænsen helt anderledes, end deres landsmænd i metropolerne gør det (op.cit.:178). For dem er grænsen ofte et konkret centrum for organiseringen af det sociale liv, der finder sted i grænse- 
regionen og hen over grænsen. Grænser skiller ikke bare to landes befolkninger. Der foregår et væld af interaktioner og udvekslinger hen over grænser med grænsen som det meningsskabende centrum. Det EU-ropæiske forsøg på at nedtone de internationale grænser vil højst sandsynligt ikke fjerne disse grænsers symbolske og sociale betydning. Men det er ikke utænkeligt, at det vil ændre den orden, som grænserne i deres nuværende form skaber (op.cit.:185).

\section{Sproglige og kulturelle grænser}

Det EU-ropæiske fors $\emptyset$ på at nedlægge internationale grænser har ikke entydigt til formål at skabe et EU uden sproglige og kulturelle grænser. Samtidig med at man forsøger at nedtone de (stats)grænser, som deler EU-ropæerne - og i øvrigt også samtidig med, at man fører en aktiv kulturpolitik, hvis formål er at skabe en kollektiv europæisk kulturel identitet (se Shore \& Black 1992, 1994; Shore 1993, 1995) - har der siden begyndelsen af 1980'erne været ført en lige så aktiv politik, der går ud på at styrke kulturelle og sproglige forskelle inden for Fællesskabet (Wilken n.d.). Og man kan godt forestille sig, at forsøgene på at svække de grænser, der i øjeblikket ordner EU i stater, vil medføre, at andre grænser skabes eller bliver tydeligere. Det er i hvert fald udgangspunktet for Parmans analyse af opsvinget for ,crofters-livsstilen“ i Skotland (Parman 1993). Crofting refererer til en særlig social og økonomisk indretning af landbrugssamfund, hvor en del af jorden ejes kollektivt og enten bruges til græsning eller cirkulerer mellem samfundsmedlemmerne (op.cit.:197). Det forbindes primært med den gælisktalende befolkning i det skotske højland og på de vestlige øer. Siden slutningen af forrige århundrede har crofting været udgangspunktet for konstruktionen af en etnisk identitet, og det har - både qua den livsstil, det involverer og qua sit gælisk/keltiske udgangspunkt - spillet en vis rolle i skotsk nationalisme (op.cit.:194-7). Men det er først i de senere år, og inden for rammerne af Den Europæiske Union, at crofting for alvor har fået central betydning. Det hænger til en vis grad sammen med systemets kulturelle og sproglige forankring. Men måden, det har fået betydning på, hænger nok så meget sammen med omlægningerne af EU's fælles landbrugspolitik (op.cit.:198). Hvor CAP'en, den fælles landbrugspolitik, tidligere har favoriseret intensive, overskudsproducerende landbrugsformer, har dens formål siden slutningen af 1980'erne været at skabe grundlag for en diversificeret landbrugsøkonomi, som beskytter småbrug, fremmer livskvaliteten og værner om miljøet navnlig i EU's periferier (ibid.).

Inden for denne ramme har crofting fået en renæssance med potentiel international rækkevidde. Eller som en avisartikel har beskrevet det:

,[...] After centuries of national neclect and even outright attack, crofting is being thrown to the forefront of European priorities, following an incredible shift in social and environmentalist demands“ (citeret i Parman 1993:198-9). Parmans analyse viser, hvordan politiske prioriteringer i EU har direkte indflydelse på livet i det nordlige Skotland. Hvor crofting ellers har haft trange kår i britisk landbrugspolitik, er det nu blevet legitimiseret som et $\emptyset$ nskværdigt $\varnothing$ konomisk diversificeret system, hvis fremtidige overlevelse sikres gennem EU's strukturfonde (op.cit.:198). Parman viser også, hvordan magtbalancen i de gælisktalende områder af Skotland er skiftet, efter at crofting - snarere end ,gælisk kultur" - er blevet det definerende træk ved det skotske højland og de vestlige øer. 
Hvor det tidligere var Comhairle nan Eilean (The Western Isles Council), der tegnede de gælisktalende samfund, er det nu den relativt nydannede The Scottish Crofters Union, der er centrum for etnicitet (ibid.). Den har forstået at udnytte de ændrede økonomiske muligheder i CAP'en, og den har formået at underbygge sin lokale position gennem alliancer med eksempelvis Royal Society for the Protection of Birds og Federation of Family Farms. Royal Society, der har flere medlemmer, end der er indbyggere på højlandet og på øerne, ,borger" for croftingsystemets økologiske forsvarlighed, og Federation of Family Farms, der repræsenterer omkring 40.000 småbønder i England, Skotland, Wales, Nordirland og Den Irske Republik, sikrer gennem sin repræsentation i Bruxelles, at fortalerne for crofting aldrig er langt væk fra de tilskudsgivende myndigheder (op.cit.:199).

Opsvinget for crofting betyder, som Parman argumenterer, at en skotsk grænse bliver tydeligere i et internationalt grænsesystem under omlægning (op.cit.:190-1). Et problem i den forbindelse, som ikke behandles i Parmans artikel, men som det nok er værd at se nærmere på, er, at crofting kulturelt og sprogligt identificeres med en bestemt del af Skotland, og at det derfor ikke så meget tydeliggør en grænse om Skotland som en grænse i Skotland, hvilket ikke nødvendigvis er uproblematisk.

\section{Vesten og Resten?}

Spørgsmålet om grænser i forbindelse med den Europæiske Union vedrører ikke bare de lande, som er med i Unionen. Unionen er i sig selv en grænseskabende enhed, hvilket har betydning for lande uden for. I såvel politologien som i den kritiske politiske diskurs om EU har man længe diskuteret de problematiske aspekter af konstruktionen af en union, der bygger på det, McBride har kaldt „From Plato to Nato“-udgaven af vestlig civilisation (se Piertse 1991:3; Shore 1993:794-5), og som lukker sig om sig selv. Fortress Europe er en af de betegnelser, der er blevet anvendt om Den Europæiske Union (Piertse:ibid.).

Det er for så vidt den tråd, Malcolm Chapman tager op i sin analyse af det polsk-tyske grænseområde (Chapman 1994). Chapmans artikel er komprimeret og vil mange ting på en gang: informere om Gatt-forhandlingerne og deres betydning for intra-EU-ropæisk politik; om World Trade Organisation og multinationale firmaers rolle i Europa; forholde sig til det ikke uinteressante spørgsmål om penges identitet (ikke den fælleseuropæiske mønt, euroen, men identiteten af de penge, der kanaliseres fra EU til Polen, og som har det med at få en - tysk - identitet på vejen); opsummere de historiske relationer mellem Polen og Tyskland og endelig forholde sig til en af Unionens ydre grænser. Og fordi den vil alt dette på 25 sider, fremstår den først og fremmest som en god idé, der bestemt bør forskes mere i og skrives mere om (på mere plads).

Spørgsmålet om Unionens ydre grænser er interessant og betydningsfuldt, og Chapman udpeger i sin artikel nogle væsentlige problemstillinger, som en forskning i konstitueringen af disse grænser bør involvere. Men valget af netop den polsk-tyske grænse som eksempel på en ydre unionsgrænse er problematisk, fordi Polen sammen med Tjekkiet og Ungarn sandsynligvis vil være blandt de næste lande, der optages. Det vil konvertere den polsk-tyske grænse med alle de problemer, det indebærer, til en indre grænse. Det gør selvfølgelig hverken området eller Chapmans forskning mindre interessant, men det ændrer unægtelig konteksten. Og faktisk er netop Polen allerede nu involveret i forskellige former for EU-relateret samarbejde. Dels har de sammen med Tjekkiet og Un- 
garn dannet sammenslutningen Visegrad, der skal forberede disse landes optagelse i EU, og dels indgår de sammen med Østrig, Ungarn, (tidligere) Jugoslavien, Tjekkiet, Slovakiet og Nordøstitalien i det heksagonale initiativ, der med Venedig som drivkraft forsøger at (gen)skabe et centraleuropæisk $ø$ konomisk fællesskab med det erklærede formål at skabe et mellemeuropæisk alternativ til den meget tysk-dominerede $\emptyset$ konomi i EU (Smith 1993:50). Og som i øvrigt er et af eksemplerne på, at opbruddet i Østeuropa har haft en helt konkret indflydelse på udviklingen i EU.

Polen tjener altså bedre som eksempel på, hvor komplicerede de europæiske grænseproblematikker er, end på hvad grænsen om EU kommer til at betyde. Skal man forholde sig til dette spørgsmål er det sandsynligvis mere interessant at se på relationerne til f.eks. Malta, Tyrkiet og Cypern, hvis ansøgninger om medlemskab længe er blevet syltet, eller til lande, som af forskellige grunde ikke ønsker at være med - Schweiz og Norge, f.eks. eller The Isle of Man. Det er mere sandsynligt, at det er i relationerne til lande, som ikke „må“ eller ikke vil være med, at EU's grænser vil blive defineret, både indefra og udefra. I forhold til f.eks. Malta og Tyrkiet har der i de senere år været en voksende tendens til, at de formelle årsager til at udskyde behandlingen af ansøgningerne om medlemskab (som for Maltas vedkommende er den store statslige sektor i maltesisk $\varnothing$ konomi og for Tyrkiets de mange overtrædelser af menneskerettighederne) underbygges med ,virkelige “ årsager, som betoner forskellene mellem Os og Dem. Den danske formand for Folketingets Europaudvalg skrev således for et par år siden, at ,den virkelige grund til tøven over for Tyrkiet som medlem af EU er i stedet, at landet til dels repræsenterer en anden kultur, samt at fri bevægelighed for arbejdskraft uden regulering ville kunne blive et markant problem i flere EU-lande“ (Fich 1994:133).

På The Isle of Man, ${ }^{3}$ som har handelspolitisk samarbejde med Den Europæiske Union, men som ikke er medlem, har de senere års diskussion om Unionens voksende indflydelse på indenrigspolitiske forhold også handlet om, hvordan man på The Isle of Man var forskellig fra europæerne i Unionen. Det er sandsynligvis i sådanne diskussioner og argumenter, hvor forskelle etableres, at EU's grænser vil få betydning. Etablering af EUgrænser er også interessant i forhold til indvandrere og flygtninge, både dem, der allerede er her, og dem, der vil komme. Det problemfelt antydes, mere end det analyseres, i McDonoughs artikel om ikke-EUropæiske indvandrere i Catalonien (McDonough 1993).

\section{Byer}

Den Europæiske Union er først og fremmest urban. Selv om „landet“ udgør omkring $80 \%$ af Unionens samlede areal, bor mere end halvdelen af EU-ropæerne i byer. I den forbindelse kan det være interessant at notere sig, at EU, som ellers har politisk koordinering og kommissioner for det meste (landbrug, fiskeri, turisme, miljø, industri, regioner, kultur og kommunikation, teknologi, eksterne relationer mv.) ikke har en „bykommission", og altså heller ikke en samlet koordineret politik i forhold til byer. Det betyder ikke, at byer er glemt - for EU finansierer byprojekter, for alt fra byøkologi på Nørrebro over renovation af Milanos slumområder til modernisering af Barcelonas havnefront men det betyder, at midlerne til EU's „,bypolitik“ hentes fra forskellige kommissioner og ikke er underlagt nogen samlet eller langsigtet planlægning. Netop manglen på en formaliseret bypolitik i EU er grundlaget for en række formelle og uformelle netværker mellem 
byer i EU. Og det er temaet for Estelle Smiths artikel „The Incidental City: Urban Entities in the EC of the 1990s", som nu ikke bare handler om byer, men også om interregionale alliancer. I de senere år har der nemlig været en enorm vækst $\mathrm{i}$ ikke-statslige netværker både inden for EU og hen over Unionens nuværende grænser.

En række af de interregionale og interurbane netværker skriver sig - forsøgsvis i hvert fald - ind i en historie, der rækker ud over både Unionskonstruktionen og den nationale organisering af de europæiske stater. Det gælder f.eks. Det Heksagonale Initiativ, Alpen-Adria- og Donau-Länder-konstruktionerne, der på forskellige måder binder områder i Centraleuropa sammen i økonomiske, forskningsmæssige, teknologiske og kulturelle netværker, og som eksplicit har til formål at give Centraleuropa en økonomisk og kulturel renæssance i Europa (Smith 1993:50). Også den genoplivede Hansestadsalliance mellem Bremen, Hamburg og Lübeck i vest og Rostock, Wismar og Stralsund i $\emptyset$ st har et historisk forbillede for deres fors $\emptyset \mathrm{g}$ på at skabe sig en central $\emptyset$ konomisk position i EU (op.cit.:51). Selv om disse (re)konstruktioner, som Smith bemærker, kan forekomme både anakronistiske og romantiserede, er de ikke desto mindre betydningsfulde i den europæiske udvikling.

Andre interurbane netværker har mere tydeligt forbindelse til den fælleseuropæiske konstruktion, og til overvejelser om byers placering i den. Som Rotterdams tidligere borgmester dr. Bram Peper har formuleret det: „If cities don't work, the EC won't work“. Det var samme dr. Peper, der i 1985 grundlagde Eurocities, der startede som en uformel forening mellem politiske ledere fra Rotterdam, Barcelona, Birmingham, Milano, Lyon og Frankfurt, men som i dag er grundstammen i et inter-EU-ropæisk urbant netværk, der også har associerede medlemmer blandt byer uden for EU, og som koordinerer løsninger på og forskningen i fælles problemer (op.cit.:52). Dr. Peper er også ophavsmand til EUricur, et netværk af byer og universiteter, og sammen fors $\varnothing$ ger de to organisationer at fremme en integreret og fremtrædende urban komponent i EU-strukturen. Samarbejdet har allerede givet sig udslag i adskillige EU-finansierede projekter, og det kan blive et vigtigt redskab $\mathrm{i}$ at flytte den $\emptyset$ konomiske vægt i EU væk fra landområderne og ind i byerne (ibid.). Eurocities er den mest betydningsfulde og omfattende byorganisation i EU, men der findes også en fransk pendant, Eurometropole, hvis væsentligste formål er at koordinere universitetsforskning og forretningslivets interesser, og som (endnu) ikke inddrager byernes politiske strukturer (ibid.). Smiths artikel udpeger et interessant antropologisk forskningsfelt, som på samme tid demonstrerer det antropologiske potentiale for at fremme forståelsen af $\emptyset$ konomiske, kulturelle og sociale processer inden for EU og bidrager til en (stadig) betrængt urban antropologi. Men også andre temaer hører hjemme under en urban antropologisk EU-forskning.

Migrationsproblematikken er, som McDonough (1993) påpeger, i udbredt grad et urbant fænomen inden for EU. Det er først og fremmest i byerne, at forskellige multietniske samfund har slået rødder. Og en forståelse af disse multietniske samfund - og forskellene på dem - hører i høj grad med til forståelsen af Den Europæiske Union. Også det voksende antal udstødte - de arbejdsløse, de hjemløse, de fattige, narkomanerne, de kriminelle - hører med til bybilledet i EU-ropa (Boissevain 1994) og bør få en plads i den antropologiske forståelse af EU. 


\section{Bønder}

Selv om bønder udgør et mindretal af EU's befolkning, fylder de meget - både i EUpolitikken og i diskussionerne om Den Europæiske Union. En stor del af EU's økonomi og politik handler om landbrug og om bønder. En række lande er eksplicit gået ind i fællesskabet på grund af landbruget. Og bønderne udgør formentlig den enkeltgruppe inden for Unionen, der om nogen har formået at inkorporere EU i deres omverdensforståelse. Bizarre historier fra det virkelige liv, som f.eks. Ærøbøndernes forsøg på at få status som højlandsbønder, eller Skjernbøndernes kreative idé om at leje Saltholmen øst for Sjælland som græsningsareal for vestjyske tyrekalve, som i øvrigt skal blive stående i staldene omkring Skjern og udløse „,handyrspræmier“ i Bruxelles, viser tydeligt, at bønderne er blevet EU-ropæere.

Antropologien har et enormt potentiale for at bidrage til forståelsen af landbrugsudviklingen i Vesteuropa. Ved at kombinere etnografiske feltstudier i lokalsamfund med studier af CAP'en har antropologer i højere grad end andre forskere, der beskæftiger sig med EU, mulighed for både at dokumentere, hvordan CAP'en virker ,ude i virkeligheden “, og at diskutere, hvorfor den virker, som den gør i forskellige europæiske lokalsamfund (Shutes 1993:124). Det er da også i forhold til landbrugssamfund, at de fleste antropologiske bidrag til EU-forskningen hidtil er kommet. Wilson (1989) har studeret irske bønders politiske og økonomiske strategier i forhold til CAP'en, Shutes (Shutes 1991, 1993) har set nærmere på kriseramte irske (og andre) mælkeproducenters tilpasningsstrategier efter omlægningen af CAP'en i midten af 1980'erne, Jurjus har sammenlignet CAP'ens forskellige virkninger i Holland og Sydspanien på baggrund af en analyse af disse landes forskellige sociale, økonomiske og politiske organisering af landbruget, og Parman (1993) har, som allerede nævnt, studeret virkningerne af de seneste CAP-omlægninger i skotske crofters-samfund (se også Giordano 1987, 1994).

Fælles for disse bidrag er, at de ser CAP'en som en ramme for landbrugsudviklingen i EU, som nok udstikker de overordnede retningslinier, men som ikke bestemmer de konkrete, lokale virkninger (Jurjus 193:99). Den sociale, politiske og økonomiske organisering af europæiske landbrug er nemlig meget forskellig, og bønder har udviklet et væld af strategier i forhold til CAP'en. Der er eksempelvis enorm forskel på, hvordan hollandske og irske bønder håndterer den nuværende krise for mælkeproducerende bønder. Mens de hollandske mælkeproducenter med støtte fra den hollandske stat - en st $\varnothing t t e$ der er mulig, fordi bønder har særlige konstitutionelle rettigheder i Holland - har satset på en storstilet udvikling af sekondærindustri til forarbejdning af mælkeprodukter (Jurjus 1993:109-15), forsøger irske mælkeproducenter at holde på deres landbrug gennem omlægning til deltidslandbrug og indtægtssupplering (Shutes 1993:138-9).

Antropologer har mulighed for både at forholde sig til CAP'ens (og andre EU-politiske foranstaltningers) virkninger i konkrete lokalsamfund og for at demonstrere, hvordan kulturelle værdier og social organisation sætter grænser for det politisk mulige. Og på grund af deres - ofte - langvarige feltarbejder i europæiske lokalsamfund har de også mulighed for at dokumentere, at CAP'en ofte virker på andet end på landbrugsproduktionen. Parmans analyse af de skotske crofterssamfund er allerede nævnt. Wilson (1993: 177) har tilsvarende en beretning om, hvordan smuglere (som næppe er en af CAP'ens målgrupper) efter Storbritanniens og Irlands optagelse i EF fandt en lukrativ niche inden for kvæg- og kornimport. Fidusen gik i al sin enkelhed ud på, at man importerede korn og 
kvæg, smuglede det over grænsen om natten, genimporterede det næste dag, og på den måde fik de samme kornladninger og det samme kvæg til at udløse stats- og EF-tilskud adskillige gange.

\section{Fællesskabskonstruktionen}

At Den Europæiske Union har endog meget stor indflydelse på de vesteuropæiske samfund og derfor nødvendigvis må indgå i antropologiske studier af vesteuropæiske samfund, skulle gerne være fremgået. Men Unionen - eller samarbejdsinstitutionerne - udgør også et antropologisk forskningsfelt i sig selv. I de senere år har flere antropologer og kulturforskere beskæftiget sig med de europæiske samarbejdsinstitutioner. En del af dem har taget udgangspunkt $\mathrm{i}$ det internationale, interkulturelle og intersproglige fundament for det europæiske samarbejde. Ejersboe (1993a, 1993b) har f.eks. analyseret den intersproglige og interkulturelle interaktion i en europæisk samarbejdsinstitution i Norditalien på baggrund af forestillinger om sammenhæng mellem sprog og kultur. Abélès (1992) har set nærmere på dagliglivet i Europaparlamentet, og Shore \& Black (1994) har beskæftiget sig med kommissionsembedsmænds kulturelle identiteter mellem det nationale og det europæiske. Der er også foretaget analyser af de fællesforestillinger om EUropa, som efterhånden vokser frem i samarbejdsinstitutionerne, og som har indflydelse på den politik, der føres. (Shore 1993, 1995) har således beskæftiget sig med grundlaget for Europakommissionens fors $\varnothing \mathrm{g}$ på at skabe en fælles europæisk kulturel identitet inden for EU, og Gulløv-Christensen (1994) har set nærmere på de forestillinger om sprog og kultur, der ligger bag den europæiske sprogundervisningspolitik, og har forholdt sig til konsekvenserne af dem.

Forskningen i europæiske samarbejdsinstitutioner er betydningsfuld for forståelsen af den europæiske fællesskabskonstruktion. Det er i samarbejdsinstitutionerne, at EUropæerne mødes, interagerer og kommunikerer hen over enorme indbildte såvel som reelle forskelle, og det er i samarbejdsinstitutionerne, at de politiske beslutninger træffes, og nye europæiske selvfølgeligheder udvikles. Og feltet er stort. Den forskning, der hidtil er blevet udført, berører kun nogle af samarbejdsinstitutionerne og udforsker kun enkelte af de problemstillinger, det kunne være relevant at få belyst.

\section{Ikke et ord om Luxembourg}

For bare 10 år siden fandtes der ingen „antropologi om Den Europæiske Union“. I dag foreligger adskillige artikler (ikke alle er medtaget her), der både dokumenterer betydningen af unionskonstruktionen i forskellige europæiske lokalsamfund, og dokumenterer disse samfunds kreative med- og modspil til EU-ropæisk politik. Og selv om mange af dem fremstår som enkeltstående bidrag til en faglig diskussion, der endnu ikke er kommet i gang, udgør de et glimrende grundlag for fremtidig forskning. Det er endnu kun en brøkdel af unionskonstruktionen, der er blevet udsat for antropologisk analyse. Der er masser af uudforskede muligheder, både når det gælder problemstillinger, og når det gælder geografisk lokalitet. Og selv om det ikke er underligt, så er i hvert fald det sidste en smule problematisk. Cole beskyldte (i 1977) Europa-antropologien for at være anglo- 
mediterran, og selv om der bestemt er sket forandringer, er der stadig store, hvide pletter på det antropologiske Europakort. De antropologiske bidrag til EU-forskningen stammer overvejende fra feltarbejder i Irland, den britiske periferi og Middelhavslandene; Danmark optræder kun i spredte bisætninger (se dog Skovgaard-Petersen 1994), Belgien nævnes i det store og hele ikke, og hvad ved vi i grunden om Luxembourg, bortset fra at det er Unionens mindste stat, og at man dér efter standardnormerne for en europæisk nationalstat har et besynderligt forhold til sprog? I det omfang, interessen for Den Europæiske Union breder sig til Europa-antropologien generelt, kan man håbe, at det medfører en bedre geografisk dækning, end den man har i øjeblikket.

\section{Noter}

1. De fire motorregioner er betegnelsen for Baden-Württemberg, Rhône-Alpes, Catalonien og Lombardiet, som har indgået et $\emptyset$ konomisk, teknologisk, uddannelses- og forskningsmæssigt samarbejde (hvortil den lille „påhængsmotor“ Wales også er knyttet), og de tegner sig sammen for den største velstandsfremgang inden for EU.

2. Storbritannien har i det hele taget givet sig til at sikre sine grænser mod Europa efter ratificeringen af Fællesakten, som konkret grundlagde arbejdet hen imod et Europa uden grænser. Således har de også investeret 10 mio. pund i grænsekontrol ved tunnellen til kontinentet (Parman 1993:193).

3. Oplysningen stammer fra et kortvarigt feltarbejde, jeg foretog på The Isle of Man i sommeren 1996.

\section{Litteratur}

Abélès, $M$.

1992 La vie quotienne au parlement européene. Paris: Hachette

Boissevain, J.

1975

Towards a Social Anthropology of Europe. I: Boissevain \& Friedl (eds.): Beyond the Community: Social Processes in Europe. The Hague: University of Amsterdam.

1994 Towards an Anthropology of European Communities? I: Goddard, Llobera \& Shore (eds.): The Anthropology of Europe: Identities and Boundaries in Conflict. Oxford: Berg.

Bull, M. J.

1993

Widening versus Deepening the European Community: The Political Dynamics of 1992 in Historical Perspective. I: Wilson \& Smith (eds.): Cultural Change and the New Europe: Perspectives on the European Community. Westview Press.

Chapman, M.

1994

The Commercial Realization of the Community Boundary. I: Goddard, Llobera \& Shore (eds.): The Anthropology of Europe: Identities and Boundaries in Conflict. Oxford: Berg.

Cole, J.

1977 Anthropology Comes Part-way Home. Annual Review of Anthropology 6:349-403.

Ejersbo, S.

1993a Visionerne fra Babel - om sprog og nationalitet i euro-europæisk kontekst.

Institut for Kultursociologi: Københavns Universitet.

1993b Et lille stykke Europa. Tidsskriftet Antropologi 28:81-90.

Fich, O.

1994 EU set fra gulvet. I: Brix et al.: EUropas Fremtid: Ved dæmonernes port.

Forlaget Hovedland. 
Giordano, C.

1987 The 'Wine-War' between Italy and France: Ethno-Anthropological Aspects of the European Community. Sociologia Ruralis 27:56-66.

Goddard, Llobera \& Shore (eds.)

1994 The Anthropology of Europe: Identities and Boundaries in Conflict. Oxford: Berg.

Grillo, R. D.

1980 Introduction. I: R. D. Grillo (ed.) "Nation" and "State" in Europe. Academic Press.

Gulløv-Christensen, J.

1994 Sprog og kultur i europæisk integration. I: J. Liep \& K. Fog Olwig (red.): Komplekse liv: Kulturel mangfoldighed i Danmark. København: Akademisk Forlag.

Jaffe, A.

1993 Corsican Identity and a Europe of Peoples and Regions. I: Wilson \& Smith (eds.): Cultural Change and the New Europe. Perspectives on the European Community. Westview Press.

Jurjus, A.

1993

Farming Styles and Intermediate Structures in the Wake of 1992. I: Wilson \& Smith (eds.): Cultural Change and the New Europe. Perspectives on the European Community. Westview Press.

Knudsen, A. \& L. Wilken

1996 Kulturelle Verdener - kultur og kulturkonflikter i Europa. Columbus.

Llobera, J. R. 1994

Anthropological Approaches to the Study of Nationalism in Europe. The Work of Van Gennep and Mauss. I: Goddard, Llobera \& Shore (eds.): The Anthropology of Europe: Identities and Boundaries in Conflict. Oxford: Berg.

MacDonald, S.

1993 Identity Complexes in Western Europe: Social Anthropological Perspectives.

I: S. MacDonald (ed.): Inside European Identities. Providence/Oxford: Berg.

McDonough, G. M.

1993 The Face Behind the Door: European Integration, Immigration and Identity. I: Wilson \& Smith (eds.): Cultural Change and the New Europe. Perspectives on the European Community. Westview Press.

Parman, S.

1993 The Future of European Boundaries: A Case Study. I: Wilson \& Smith (eds.): Cultural Change and the New Europe. Perspectives on the European Community. Westview Press.

Piertse, J. N.

1991

Fictions of Europe. Race and Class 32(3):3-10.

Ruane, J. 1994

Nationalism and European Community Integration: The Republic of Ireland. I: Goddard, Llobera \& Shore (eds.): The Anthropology of Europe: Identities and Boundaries in Conflict. Oxford: Berg.

Ruane \& Todd

1991

Ireland - North and South - and European Community Integration. I: Hainsworth (ed.): Breaking and Preserving the Mould: The Third Direct Election to the European Parliament (1989) - The Irish Republic and Northern Ireland. Belfast: Polity Research Institute.

Shore, C.

1993 Inventing the 'People's Europe': Critical Approaches to European Community 'Cultural Policy’. Man 28:779-800.

1995 European Commission Bureaucrats and the Question of European Consciousness. I: Cohen \& Rapport (eds.): Questions of Consciousness. London: Routledge. 
Shore, C. \& A. Black

1992 The European Communities and the Construction of Europe.

Anthropology Today 8(3):10-11.

1994 Citizens' Europe and the Construction of European Identity. I: Goddard, Llobera \& Shore (eds.): The Anthropology of Europe: Identities and Boundaries in Conflict. Oxford: Berg.

Shutes, M. T.

1991 Kerry Farmers and the European Community: Capital Transactions in a Rural Irish Parish. Irish Journal of Sociology 1:1-17.

1993 Rural Communities without Family Farms? Family Dairy Farming in the Post-1993 EC. I: Wilson \& Smith (eds.): Cultural Change and the New Europe: Perspectives on the European Community. Westview Press.

Skovgaard-Petersen, E.

1994 Stemmer om Maastricht. I: J. Liep \& K. Fog Olwig (red.): Komplekse liv: Kulturel mangfoldighed i Danmark. København: Akademisk Forlag.

Smith, E. M

The Incidental City: Urban Entities in the EC of the 1990s. I: Wilson \& Smith (eds.): Cultural Change and the New Europe. Perspectives on the European Community. Westview Press.

Varenne, $\mathrm{H}$.

1994

Questions of European Nationalism. I: Goddard, Llobera \& Shore (eds.): The Anthropology of Europe: Identities and Boundaries in Conflict. Oxford: Berg.

Wilken, L. n.d.

One Union, Many Languages: Languages and Cultural Identities in the European Union. (under udgivelse).

Wilson, T. M.

1993 Frontiers go but Boundaries Remain: The Irish Border as a Cultural Divide. I: Wilson \& Smith (eds.): Cultural Change and the New Europe. Perspectives on the European Community. Westview Press.

Wilson \& Smith (eds.)

1993 Cultural Change and the New Europe. Perspectives on the European Community. Westview Press. 